\title{
The Basis for the Implication of Powers of International Organizations
}

\section{Introduction}

A previous edition of the Adam Mickiewicz University Law Review contained my article on the doctrine of implied powers of international organizations in the case law of international tribunals. ${ }^{1}$ In its conlusion, a claim was formulated that the case law of the Permanent Court of International Justice (PCIJ) and the International Court of Justice (ICJ) formed, and still form, the intellectual basis for the analysis of issues concerning the implied powers of international organizations in the doctrine of international law. This article is the continuation of considerations on the topic of implied powers of international organizations, with a particular focus on the basis of the implication of such powers.

Undoubtedly, any academic discussion on this matter must acknowledge the nature of these powers as being additional to the powers expressly granted in constituent instruments. These expressly granted powers therefore form the first basis for implying additional powers. Another basis for implying powers is provided by the purposes and functions of a given international organization. Both these bases were referred to in the case law of the Court of Justice of the European Union (CJEU), but it is worth pointing out that the Court preferred the latter and quoted express powers much less frequently. This is undobtedly connected with the concept of functional necessity. It should be noted,

1 A. Gadkowski, The doctrine of implied powers of international organizations in the case law of international tribunals, “Adam Mickiewicz University Law Review” 2016, vol. 6, pp. 45-59. 
however, that the preference for using the purposes and functions of an international organization when implying its powers carries certain risks. In this context, Krzysztof Skubiszewski points to situations where it is impossible to separate the purposes and functions of an international organization from its existing powers, which, in practice, makes it impossible to treat these powers and functions alone as a sufficient basis for implication. ${ }^{2}$ In practice such a situation clearly results in limiting the doctrine of implied powers.

For example, Manuel Rama-Montaldo, who himself is no supporter of a strict differentiation between the functions and powers of international organizations, is of the opinion that the statutes of most international organizations "do not draw any such distinction between function and powers, and either use those words indiscriminately or else rather tend to use the word function."3 The UN Charter is a good example of this.

Luigi Ferrari Bravo and Andrea Giardina, who thoroughly discussed this matter in the context of the Treaty on the European Community (TEC), also identify the concept of implied functions. In the comments on Article 235 of the TEC and based on the analysis of the 1962 Certain expenses ICJ advisory opinion ${ }^{4}$, they argue that while implied powers are used to perform functions that have already been assigned to the organization, the concept of implied functions refers to those tasks of this organization which, although not expressly assigned to it, are "necessary for the fulfilment of its ends." 5

It can be said therefore, that the functions of an international organization are related to the essence of its activity and, by extension,

2 K. Skubiszewski, Implied Powers of International Organizations, in: International Law at a Time of Perplexity. Essays in Honour of Shabatai Rosenne, ed. Y. Dinstein, Dordrecht 1989, p. 857.

3 M. Rama-Montaldo, International Legal Personality and Implied Powers of International Organizations, “44 British Yearbook of International Law” 1970, p. 151.

4 Certain expenses of the United Nations (Article 17, paragraph 2, of the Charter), Advisory Opinion of 20 July 1962, ICJ Reports 1962, p. 157 et seq.

5 L. Ferrari Bravo, A. Giardina, Commentario al Trattato Istitutivo della CEE, vol. III, Milano 1965, p. 1702; M. Rama-Montaldo, International Legal Personality..., p. 150. 
to the tasks it fulfils. Powers, on the other hand, by their very nature concentrate on measures which are taken by the organization and which produce certain legal effects, both for the organization itself and its member states. There is also no doubt about the connection between the functions and powers of an international organization. This relationship may be illustrated by the concept of implied powers. Implied powers are, after all, powers which, although additional, are necessary or essential for the performance of the organization's statutory functions.

A broad definition or determination of the functions and purposes of an organization in its statute is certainly beneficial from the point of view of assuming additional powers, such as implied powers. In order to imply real and effective additional powers, however, it is important that the constituent instrument provide the international organization with a certain catalogue of express powers and a mechanism for implying these additional powers. International organizations operate in a dynamic international reality. Their statutes often comprise provisions that retain their initial form and shape for decades, despite substantial changes in the international environment. As we know, so far it has been impossible to review the United Nations (UN) Charter, whose provisions have hardly changed for 70 years. Implying additional powers is, therefore, necessary to ensure that the organization exercises the powers expressly granted to it and fulfils its statutory purposes and functions.

\section{The Purposes and Functions of International Organizations as the Basis for Implication}

In practice, the definition of the purposes, tasks and functions of international organizations in their constituent instruments is often extremely broad. The real meaning of these terms is consequently often unclear and results in many possible interpretations acting as bases for the implication of powers of international organizations. One needs therefore to highlight 
selected decisions of international courts, in which these courts based implied powers on the purposes and functions of international organizations. In the Work of the Employer case, the PCIJ stated that the International Labour Organization (ILO) would be prevented from "the accomplishment of [its] end"6, i.e. the protection of workers and the ensuring of acceptable labour conditions, if the organization could not regulate incidentally the work performed by the employers. The Court's position on the matter, however, was based on more extensive reasoning. It also cited the intention of the states parties to the Treaty of Versailles and the interpretation of the Treaty's provisions. ${ }^{7}$ Another PCIJ opinion, the Danube advisory opinion, contains references to the limits of the functions expressly bestowed upon the European Commission of the Danube. More precisely, the Court held that the European Commission as "an international institution with a special purpose [...] only has the functions bestowed upon it by the Definitive Statute with a view to the fulfilment of that purpose, but it has power to exercise these functions to their full extent."

An interesting reference to the purposes and functions of an international organization was made by the ICJ in the well-known 1949 Reparation for injuries case. In this advisory opinion, the Court used general language to justify the UN's power to bring international claims. Based on the assumption that the organization is an international legal person, the Court stated that "the rights and duties of an entity such as the Organization must depend upon its purposes and functions as specified or implied in its constituent documents and developed in practice.”9

6 Competence of the ILO to regulate Incidentally the Personal Work of the Employer, PCIJ Publications 1926, Series B - No. 14, p. 18.

7 For an analysis of this opinion, see J. Makarczyk, The International Court of Justice on the Implied Powers of International Organizations, in: Essays in International Law in Honour of Judge Manfred Lachs, ed. J. Makarczyk, The Hague 1984, p. 506.

8 Jurisdiction of the European Commission if the Danube between Galatz and Braila, PCIJ Publications 1927, Series B - No. 14, p. 64.

9 Reparation for injuries suffered in the service of the United Nations, Advisory Opinion, ICJ Reports 1949, p. 180. 
Consequently, the ICJ elaborated on its position stating: "the Organization must be deemed to have those powers which, though not expressly provided in the Charter, are conferred upon it by necessary implication as being essential to the performance of its duties.”10

It should be noted that the view presented in this opinion was later reflected in the Effect of awards case. In this advisory opinion, the ICJ implied the power to establish an administrative tribunal as follows: "[t]he power to establish a tribunal, to do justice as between the Organization and the Staff members, was essential to ensure the efficient working of Secretariat [...] capacity to do this arises by necessary intendment out of the Charter." 11 The ICJ also referred to the statutory purposes of an organization in the Certain expenses case. In its interpretation of the UN Charter, the Court concluded that "when the Organization takes action which warrants the assertion that it was appropriate for the fulfilment of one of the stated purposes of the United Nations, the presumption is that such action is not ultra vires the Organization.”12

Another reference to the UN's functions regarding the trusteeship system may be found in the Status of South West Africa advisory opinion. The ICJ implied the UN's supervisory power over the South West African territory, even though the territory had not been placed in the trusteeship system. In this case the ICJ relied on the necessity for supervision. According to the Court, "[t]he necessity for supervision continues to exist despite the disappearance of the supervisory organ under the Mandates system. It cannot be admitted that the obligation to submit to supervision has disappeared merely because the supervisory organ has ceased to exist, when the United Nations has another international organ performing similar, though not identical, supervisory functions." ${ }^{13} \mathrm{Fi}$ -

10 Ibidem, p. 182. For an analysis of this opinion, see for example: B. Conforti, C. Focarelli, The Law and Practice of the United Nations, The Hague 2005, p. 13 et seq.

11 Effect of Awards of Compensation made by the U.N. Administrative Tribunal, Advisory Opinion, ICJ Reports 1954, p. 57.

12 Certain expenses case, op. cit., p. 168.

13 International status of South-West Africa, Advisory Opinion, ICJ Reports 1950, p. 136. 
nally, in the Legality of the Use by a State of Nuclear Weapons in Armed Conflict case, the ICJ cited the criteria of implying powers previously used in the Reparation for injuries and Effect of awards cases. It concluded that implied powers signify "powers which [...] are conferred upon [the Organization] by necessary implication as being essential to the performance of its duties."14

It should be emphasized that the ICJ did not, however, accept the WHO's power to request an advisory opinion. The ICJ held that "it does not seem to the Court that the provisions of Article 2 of the WHO Constitution [which determine the functions of the WHO] [...] can be understood as conferring upon the Organization a competence to address the legality of the use of nuclear weapons, and thus in turn a competence to ask the Court about that." 15

In addition, one should also note an interesting construct introduced in the Namibia case. Here, the Court sought the power to revoke a mandate when no such power was expressly stipulated in any of the applicable international instruments. It would seem that, since the ICJ could not imply powers from those expressly stated in the treaties, it would seek such powers in the purposes and functions of the organization. The Court chose, however, to justify its position differently, and it stated that "[t]he silence of a treaty as to existence of such right cannot be interpreted as implying the exclusion of a right which has its source outside of the treaty, in general international law, and is dependent on the occurrence of circumstances which are not normally envisaged when a treaty is concluded." ${ }^{16}$ In his analysis of this opinion, Skubiszewski points out the ICJ 'presumption' in this context. ${ }^{17}$ In conclusion, the ICJ stated: "[t]hat this special right of appeal was not in-

14 Legality of the Use by a State of Nuclear Weapons in Armed Conflict, Advisory Opinion, ICJ Reports 1996, p. 79, para. 25.

15 Ibidem, para. 21.

16 Legal Consequences for States of the Continued Presence of South Africa in Namibia (South West Africa) notwithstanding Security Council Resolution 276 (1970), Advisory Opinion, ICJ Reports 1971, p. 47, para. 96.

17 K. Skubiszewski, Implied Powers..., p. 865; J. Makarczyk, The International Court of Justice..., p. 510. 
serted in the Covenant cannot be interpreted as excluding the application of the general principle of law according to which a power of termination on account of breach, even if unexpressed, must be presumed to exist as inherent in any mandate, as indeed in any agreement."18

In this context, one should also refer to the case law of the Court of Justice of the European Union (CJEU), which provides examples of decisions in which powers of the Community were implied from its purposes and functions. It should be noted that the Court was just as cautious about using this basis for the implication of powers as the ICJ had been. Implying the Community's powers based on the Court's case law was not, in fact, of great importance because, as the author emphasised earlier, in Community law, similarly to EU law today, there was a mechanism for determining new powers under Article 308 of the TEC (Article 352 of the Treaty of the Functionning of the European Union (TFEU)). Some decisions of the Court are nevertheless worthy of attention and as such are frequently cited in the literature. The present author shall discuss several of these by way of example only. In one of the earliest decisions, the 8/55 Fédération Charbonnière de Belgique v High Authority case, the European Court of Justice (ECJ) implied certain powers of the European Coal and Steel Community (ECSC) from the objectives of the constituent treaty. It must be emphasised, however, that the Court relied on this basis for implication in a subsidiary way only and the implied powers were, in fact, based on the express powers of the organization. The Court expressed its view as follows: "without having recourse to a wide interpretation it is possible to apply a rule of interpretation generally accepted in both international and national law, according to which the rules laid down by an international treaty or a law presuppose the rules without which that treaty or law would have no meaning or could not be reasonably and usefully applied."19

18 Namibia case, op. cit., p. 48, para. 98.

19 C-8/55 Fédération Charbonnière de Belgique v. High Authority of the European Coal and Steel Community [1954-1956], ECR-292, p. 299. 
The CJEU also formulated its stance on the matter in the most frequently cited judgment in this context, the ERTA case. In this case the Court stressed the need to consider the whole scheme of the EEC Treaty when implying powers, and invoked the transport-related objectives of the Treaty in order to demonstrate the existence of the external powers of the Community, i.e. its powers to conclude agreements in this regard. The Court concluded that this authority of the Community arises "not only from an express conferment by the Treaty [...] but may equally flow from other provisions of the Treaty and from measures adopted, within the framework of those provisions, by the Community institutions."20

\section{The Express Powers of International Organizations as the Basis for Implication}

To start with, one may say that powers of international organizations expressly granted in their constituent instruments would seem to be a sufficient basis for implying further powers. These further powers will clearly be additional powers, i.e. subsidiary to express powers. No comprehensive statutory allocation of the powers of international organizations is possible and international organizations operate in a dynamic and constantly changing international reality, which means that exercising their express powers exactly as provided for in their constituent instruments may raise concerns. A response to such a new reality might clearly be provided by amending the statute. As the example of the subsequent EU Treaties shows, not only may one in this way change the legal status of an international organization, but one may also modify its powers. On the other hand, the example of the UN demonstrates that, when faced with the lack of political will to introduce significant changes to the statute, the organization must operate in this new environment often based on outdated or ineffective statutory provisions. In such a case the powers that are implied from previously granted origi-

20 C-22/70 Commission v. Council (ERTA case) [1971], ECR-263, para. 16. 
nal powers offer a solution that, in practice, allows the performance of the statutory purposes of the organization. As in the UN Charter there is no mechanism for creating new powers based on existing powers (such as in Article 352 of the TFEU) for this organization and the implication of powers, especially those regarding external relations, may add a new meaning to the previously granted express powers.

When it comes to the ICJ stance on this matter, one should note the Court's lack of enthusiasm with regard to implying the UN's powers in this way and justifying implied powers with powers expressly granted. This view of the ICJ is illustrated by the Reparation for injuries case. When implying the powers of the UN in order to bring international claims for damage, the ICJ relied on the purposes and functions of the organization and stated that "the rights and duties of an entity such as the Organization must depend upon its purposes and functions as specified or implied in its constituent documents and developed in practice.”21

It is worth noting that the ICJ's position was not unanimous, as demonstrated by the dissenting opinion of Judge Hackworth, who sought to limit any implication of the powers of this international organization to existing powers alone. In this particular case, he based the authority of the UN to make such claims on the express provisions relating to the competences and capacities of the organization provided for in Articles 104 and 105 of the UN Charter and the 1946 Convention of the Privileges and Immunities of the UN. In this context, Judge Hackworth stressed that if the organization was able to exercise these capacities and competences, it must also "be able to assert claims on its own behalf." Therefore, "the organization must have and does have ample authority to take needful steps for its protection against wrongful acts for which Member States are responsible.”22 The essence of Judge Hackworth's view regarding the implication of powers is captured by the following statement: “[p]owers not expressed cannot freely be implied. Implied 
powers flow from a grant of expressed powers, and are limited to those that are 'necessary' to the exercise of powers expressly granted."23

It could be said that the relevance of Judge Hackworth's doubts over the possibility of implying the powers of international organizations seem to persist today. According to the author of this work, this is demonstrated by the fact that the international instruments of some international authorities substantially limit the scope of what may be implied in their functioning. The 1982 United Nations Convention on the Law of the Sea provides an apt example of this. Article 157(2), which delimits the powers of the International Seabed Authority, stipulates that "[t]he powers and functions of the Authority shall be those expressly conferred upon it by the Convention. The Authority shall have such incidental powers, consistent with the Convention, as are implicit in, and necessary for, the exercise of those powers and functions with respect to activities in the Area."24 The provisions of this article allow, albeit to a limited extent, the use of implied powers. In this particular case, the capacity of the International Seabed Authority (ISA) to imply powers depends on whether the power in question is based on the provisions of the Convention and whether it is necessary with respect to the ISA's activities.

If we are to refer this stance to the position taken by the CJEU, then, similar to the ICJ advisory opinion in the Reparation for injuries case, which reflects the somewhat unclear position of the ICJ on the doctrine of implied powers, in the CJEU case law an example is provided by the afore-mentioned ERTA case. Even the earlier decision in the 8/55 Fédération Charabonnière case indicates that the Court, when implying powers of the ECSC, relied both on the express powers of this organization and, in a subsidiary way, on its purposes and functions. The Court applied an interpretation according to which the rules of an international agreement presuppose the existence of rules "without which that treaty or law would have no meaning or could not be

23 Ibidem, p. 198.

24 United Nations Treaty Series (UNTS), vol. 1833, p. 3. 
reasonably and usefully applied.”25 In contrast, in the classic opinion of the ERTA case the CJEU implied the powers of the Community to conclude agreements on transport from its express powers, but it also referred to the whole scheme and the objectives of the Treaty. The essence of the Court's view on the matter boils down to the statement that the Community's power in question exists not only if it is expressly stated in the specific provisions of the Treaty, but may also "flow from other provisions of the Treaty and from measures adopted, within the framework of those provisions, by the Community institutions." 26

In consequence, the Court then elaborated and concluded that, if the Community has internal competence, it follows that it also has external competence, a fact usually referred to as the principle of parallelism. ${ }^{27}$ When elaborating on this doctrine, the Court also imposed limits on such implications of external powers and introduced to the principle of parallelism the test of necessity. In its developed form, this test means that the attainment of specific objectives of the TEC in the external sphere must be inextricably connected with the performance of internal acts in a given field of co-operation. ${ }^{28}$

\section{Concluding Remarks}

Based on the decisions of international courts, as discussed above, we may observe that implying the powers of international organizations from their expressly granted powers entails certain problems. When relying on expressly granted powers, such as the basis for implying the powers of international organizations in external relations, the courts also usually indicated other conditions that prevented free implication of powers. The pro-

25 C- 8/55 Fédération Charbonnière... p. 299.

26 ERTA case, op. cit, p. 274, para. 16.

27 See Opinion 1/76 Draft Agreement establishing a European laying-up fund for inland waterway vessels [1977], ECR-741.

28 Opinion 1/94 Competence of the Community to conclude international agreements concerning services and the protection of intellectual property Art 228 (6) of the EC Treaty [1994], ECR I-5267 
cess of implying the powers of international organizations must be applied with caution, but this category of powers of international organizations in external relations has been established in practice. Contrary to Finn Seyersted's opinion, it is certainly no fiction. ${ }^{29}$ Implying the powers of various entities is never easy, regardless of whether international law, EU law or national law is involved. The judgment on the McCulloch case, which initiated the doctrine of implied powers, also points to potential and real problems faced by the US Supreme Court in this case. ${ }^{30}$

\section{References}

Conforti B., Focarelli C., The Law and Practice of the United Nations, The Hague 2005.

Engström V., Understanding Powers of International Organizations. A Study of the Doctrines of Attributed Powers, Implied Powers and Constitutionalism - with a Special Focus on the Human Rights Committee, Turku 2009.

Ferrari Bravo L., Giardina A., Commentario al Trattato Istitutivo della CEE, vol. III, Milano 1965.

Gadkowski A., The doctrine of implied powers of international organizations in the case law of international tribunals, "Adam Mickiewicz University Law Review” 2016, vol. 6.

Gadkowski A., Treaty-making powers of international organizations, Poznań 2018.

Klabbers J., An Introduction to International Instituitional Law, Cambridge 2015.

29 In Seyersted's opinion, given the dynamic development of international organizations, the concept of implied powers may be too blunt a tool for describing the true scope of the powers of international organizations, see F. Seyersted, United Nations Forces, "37 British Yearbook of International Law" 1961, p. 455. Seyersted even called it 'a fiction of "implied powers' noted that even the ICJ referred to this 'fiction' in the initial years of its activity, see Common Law of International Organizations, Leiden 2008, p. 65.

30 See A Gadkowski, Treaty-making powers of international organizations, Poznań 2018, p. 125 et seq. 
Makarczyk J., The International Court of Justice on the Implied Powers of International Organizations, in: Essays in International Law in Honour of Judge Manfred Lachs, ed. J. Makarczyk, The Hague 1984.

Rama-Montaldo M., International Legal Personality and Implied Powers of International Organizations, "44 British Yearbook of International Law” 1970.

Seyersted F., United Nations Forces, “37 British Yearbook of International Law” 1961.

Seyersted F., Common Law of International Organizations, Leiden 2008.

Skubiszewski K., Implied Powers of International Organizations, in: International Law at a Time of Perplexity. Essays in Honour of Shabatai Rosenne, ed. Y. Dinstein, Dordrecht 1989.

\section{SUMMARY}

\section{The Basis for the Implication of Powers of International Organizations}

The aim of this article is to present the basis of the implication of powers of international organizations. This topic is not only of great interest and import from the point of view of the theory of international organizaizations, but also from that of the practice of international organizations, particularly important institutions of international cooperation. The author discusses the nature of the basis for such implication before then examining the implication of powers within the context of international organizations' expressly granted powers.

Keywords: International organizations, International Court of Justice, Permanent Court of Intrenational Justice, Court of Justice of the European Union, powers of international organizations. 
80 | Adam Mickiewicz University Law Review

Andrzej Gadkowski, Faculty of Law, Canon Law and Administration of the John Paul II Catholic University of Lublin, Al. Racławickie 14, 20-950 Lublin, Republic of Poland, e-mail: andrzej.gadkowski@kul.pl.

DOI 10.14746/ppuam.2020.11.04 